\title{
Increase in number of the gap junctions between satellite neuroglial cells during lifetime: An ultrastructural study in rabbit spinal ganglia from youth to extremely advanced age
}

\author{
C. Martinelli, P. Sartori, S. De Palo, M. Ledda, E. Pannese* \\ Institute of Histology, Embryology and Neurocytology, University of Milan, Via Mangiagalli 14, I-20133 Milan, Italy \\ Received 14 March 2005; received in revised form 2 May 2005; accepted 5 May 2005 \\ Available online 23 June 2005
}

\begin{abstract}
This study investigated quantitative aspects of the gap junctions between satellite neuroglial cells that envelope the spinal ganglion neurons in rabbits aged 1 year (young), 3.6 years (adult), 6.7 years (old), and 8.8 years (very old). Both the total number of gap junctions present in $30,000 \mu \mathrm{m}^{2}$ of surface area occupied by perineuronal satellite cells, and the density of these junctions increased throughout life, including the extremely advanced age. By contrast, the mean length of individual gap junctions did not change with age. Thus, the junctional system which provides morphological support for the metabolic cooperation between satellite cells in rabbit spinal ganglia becomes more extensive as the age of the animal increases. These results support the hypothesis that the gap junctions between perineuronal satellite cells are involved in the spatial buffering of extracellular $\mathrm{K}^{+}$and in neuroprotection.
\end{abstract}

(C) 2005 Elsevier Inc. All rights reserved.

Keywords: Aging; Dorsal root ganglia; Neuron-glia interactions; Peripheral neuroglia

\section{Introduction}

Neuroglial cells were long believed to simply provide structural support for neurons. However, evidence has now accumulated to show that these cells closely and actively interact with neurons in most functions of the nervous system (e.g. see [17]). As a result, interest in neuroglial cells and their interactions with neurons has greatly increased.

We have been studying the neuroglial cells that envelope the neurons in sensory ganglia for many years (for reviews, see $[26,27])$. These cells are usually called satellite cells and will be referred to as such in what follows. The satellite cells comprising a given perineuronal sheath are coupled to each other via gap junctions $[11,19,25,26,28,29]$. Gap junctions are important because they make possible metabolic cooperation between cells (e.g. see $[2,39])$ which in turn enhances

\footnotetext{
* Corresponding author. Present address: Viale S. Michele del Carso 15, I-20144 Milano, Italy. Tel.: +39 0250314660; fax: +39 0250314670.

E-mail address: ennio.pannese@unimi.it (E. Pannese).
}

the efficiency of satellite cells in their role of meeting the demands of the neurons with which they are associated.

Information on age-related changes of the gap junctions between perineuronal satellite cells is still incomplete. In this study, we report our findings on gap junctions in the spinal ganglia of rabbits from the young to the extremely advanced age.

\section{Materials and methods}

The present study was carried out on rabbits (Oryctolagus cuniculus) of both sexes. Rabbits aged 1 year (three animals, 3.4-3.5 kg body weight), 3.6 years (three animals, $3.6-3.8 \mathrm{~kg}$ body weight), 6.7 years (three animals, $4.0-4.2 \mathrm{~kg}$ body weight), and 8.8 years (three animals, $4.2-4.5 \mathrm{~kg}$ body weight) were used. The rabbits were cared for according to the European Community Council Directive (86/609/EEC) on the use of laboratory animals. The dates of birth of all animals were documented; all had been raised by a specialist 
rabbit breeder with particular attention to hygiene and regular veterinary inspections and had been fed an unrestricted diet. Because the mean life span of the normal healthy Oryctolagus is approximately 5.6 years [12] and the maximal life span is approximately 8 years [38], the 1-year-old rabbits were young, the 3.6-year-old rabbits were adult, the 6.7-year-old rabbits were old, and the 8.8-year-old animals were very old.

The animals were perfused transcardially with a solution containing $2 \%$ formaldehyde and $2 \%$ glutaraldehyde in $0.1 \mathrm{M}$ sodium cacodylate buffer ( $\mathrm{pH}$ 7.3) under deep anaesthesia with Nembutal i.p. $(80 \mathrm{mg} / \mathrm{kg})$. After fixation for about $3 \mathrm{~h}$, the thoracic spinal ganglia were removed, washed in cacodylate buffer $(0.2 \mathrm{M}, \mathrm{pH} 7.3)$ for $2 \mathrm{~h}$ and then postfixed on ice for $1.5 \mathrm{~h}$ in $2 \% \mathrm{OsO}_{4}$, buffered with $0.1 \mathrm{M}$ sodium cacodylate. The specimens were washed in distilled water, stained with $2 \%$ aqueous uranyl acetate, dehydrated in alcohol, and embedded in Epon-Araldite resin.

As even during optimum fixation, dehydration and embedding there is some degree of cellular swelling or shrinkage, to study the surface area occupied by perineuronal satellite cells and the length of each gap junction a basic assumption was that any artifactual surface area and length changes were about the same in all four age groups. This assumption seems justified by the fact that all the ganglia used for the study satisfied the following conditions: (a) the interval between the nerve cell body and the enveloping satellite cell sheath was of uniform width; (b) the clefts between the satellite cells were of constant width; (c) neither nerve cell bodies nor perineuronal satellite cells showed signs of swelling or shrinkage; (d) neither empty areas nor clumping were observed in the connective tissue space surrounding the satellite cell sheaths. Overall, 96 ganglia (8 for each animal) were used for this study.

Isotropic uniform random (IUR) sections were obtained following the orientator procedure [20]. For each ganglion, a single IUR thin section (about $0.15 \mathrm{~mm} \times 0.10 \mathrm{~mm}$ ) was photographed under the electron microscope. Each section was photographed in its entirety at a magnification of $8000 \times$ and the negatives printed to a final magnification of $32,000 \times$. A montage of 60-70 prints was necessary to reconstruct each section. The following were determined in each section: (1) the total number of gap junctions occurring between perineuronal satellite cells; (2) the length of each gap junction; (3) the total surface area occupied by perineuronal satellite cells. This area was measured with the aid of a digitizing tablet connected to a computer. Subsequently, the mean number of gap junctions per unit of surface area $\left(100 \mu \mathrm{m}^{2}\right)$ occupied by satellite cells was calculated for each rabbit (eight ganglia). The mean length of gap junctions for each rabbit was also calculated.

The values obtained for the three rabbits in each age group were compared by one-way ANOVA to establish whether they differed significantly. Subsequently, the values obtained for each age group were compared by one-way ANOVA. When ANOVA revealed significant differences, the post hoc Tukey test for multiple comparisons was used to iden- tify differences between individual age groups. Values were expressed as means \pm S.E.M. Both for ANOVA and post hoc Tukey test, differences were considered significant for $P$ values $<0.01$.

\section{Results}

The morphological relationships between nerve cell body and satellite cells did not change with advancing age. Gap junctions were never observed at the neuron-satellite cell boundary, but in all age groups occurred between the satellite cells comprising a single perineuronal sheath (Fig. 1). As described in the literature (e.g. see $[4,30]$ ), at these junctions, the normal intercellular space was abruptly reduced to about $2 \mathrm{~nm}$. The width of this gap remained constant throughout the junctional area. Most gap junctions occurred singly; occasionally they were found close to adhering junctions. Sometimes mitochondria were close to gap junctions (Fig. 1), but it was not clear whether this association had some functional significance or was due to chance.

The mean densities of gap junctions (numbers of junctions per unit of surface area $\left(100 \mu \mathrm{m}^{2}\right)$ occupied by perineuronal satellite cells) did not differ significantly between the three rabbits of each age group. In each age group we examined a total surface area occupied by perineuronal satellite cells of $30,000 \mu \mathrm{m}^{2}$. Both the total number of gap junctions found in this area, and the density of these junctions increased progressively with age. Fig. 2A shows the density of gap junctions in the four age groups. The differences between the density of gap junctions in very old rabbits and those in young, adult, and old animals were significant $(P<0.01$, in all cases).

The mean length of individual gap junctions did not differ between the three rabbits of each age group, or between the four age groups (Fig. 2B).

\section{Discussion}

In the rabbit, both the total number of gap junctions present in a surface area of $30,000 \mu \mathrm{m}^{2}$ and the mean density of these junctions increased progressively throughout life, including the extremely advanced age. By contrast, the mean size of individual gap junctions did not change with age. These findings indicate that the total area of this system of junctions increases throughout life.

To our knowledge, the relationships between aging and number or total area of gap junctions, studied in the electron microscope using strict criteria for identifying these junctions $[4,30]$, have not been investigated in other regions of the nervous system. However, the literature contains reports on the relationships between aging and gap junctions that are based on other approaches. For example, Cotrina et al. [7] revealed connexins immunohistochemically and observed that the coupling between astrocytes in the mouse brain did not change significantly with age. Further studies are required 


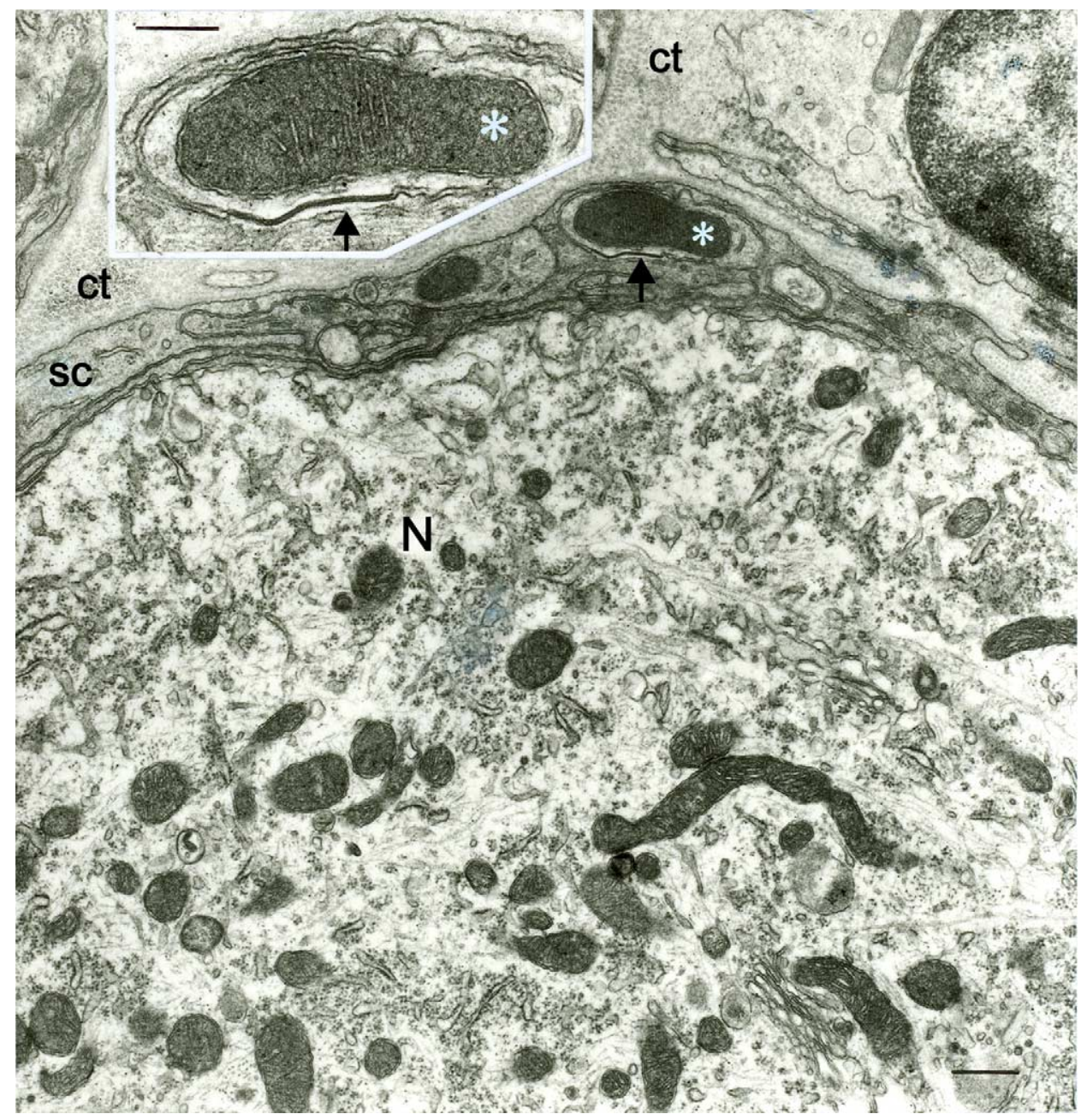

Fig. 1. Electron micrograph showing a gap junction (arrow) within a perineuronal satellite cell sheath (sc); ct: connective tissue, N: nerve cell body of a sensory neuron. The asterisk indicates a mitochondrion close to the gap junction. The latter is shown at greater enlargement in the inset. Spinal ganglion from a very old rabbit (8.8 years). Scale bar: $0.5 \mu \mathrm{m}$. Inset: scale bar: $0.25 \mu \mathrm{m}$.

to determine whether the number and total area of gap junctions, and gap junction coupling change with age in different species and in different regions of the nervous system. Studies on relationships between age and density, and age and size of gap junctions have been carried out in pure fibroblast cultures [16]. The authors reported that gap junctions were more sparsely distributed and distinctly smaller in old than young cultures. Our findings, that gap junctions are more numerous in very advanced age and that the mean size of individual gap junctions remains constant with age, are in sharp contrast to these in vitro findings. This discrepancy could be due to the difference in cell type or to differences between pure cell cultures and ganglia. The cultured fibroblasts of Kelley et al. [16] were only in contact with each other and thus gap junction formation between them depended exclusively on their intrinsic properties. By contrast, in the ganglia we studied, satellite cells were under the influence of the sensory neurons they surrounded. It is known, for example, that central nervous system neurons may influence the formation of astrocyte gap junctions (for review, see [32]).
With regard to the functions of the gap junctions between satellite cells, the following hypotheses seem the most plausible. (1) $\mathrm{K}^{+}$concentration increases in the perineuronal environment as a result of neuronal activity and a rapid removal of this excess $\mathrm{K}^{+}$is required to maintain neuronal excitability (for review, see [33]). It is widely accepted that astrocytes play a major role in the spatial buffering of extracellular $\mathrm{K}^{+}$within the central nervous system (e.g. see $[8,13,18,24]$ ). Satellite cells are believed to perform the same function in sensory and autonomic ganglia (for reviews, see [26,27]). The satellite cells closest to the enclosed neuron may take up the extracellular $\mathrm{K}^{+}$into their cytoplasm and redistribute it to the other satellite cells within the sheath. $\mathrm{K}^{+}$would eventually be discharged into the connective tissue space or returned to the neuron. Studies on the central nervous system have shown that gap junctions between neuroglial cells improve the buffering capacity of these cells (e.g. see $[14,22])$. It is likely that the gap junctions between satellite cells in sensory ganglia have the same function. (2) Neurons cultured in vitro are less vulnerable to various types of insult 

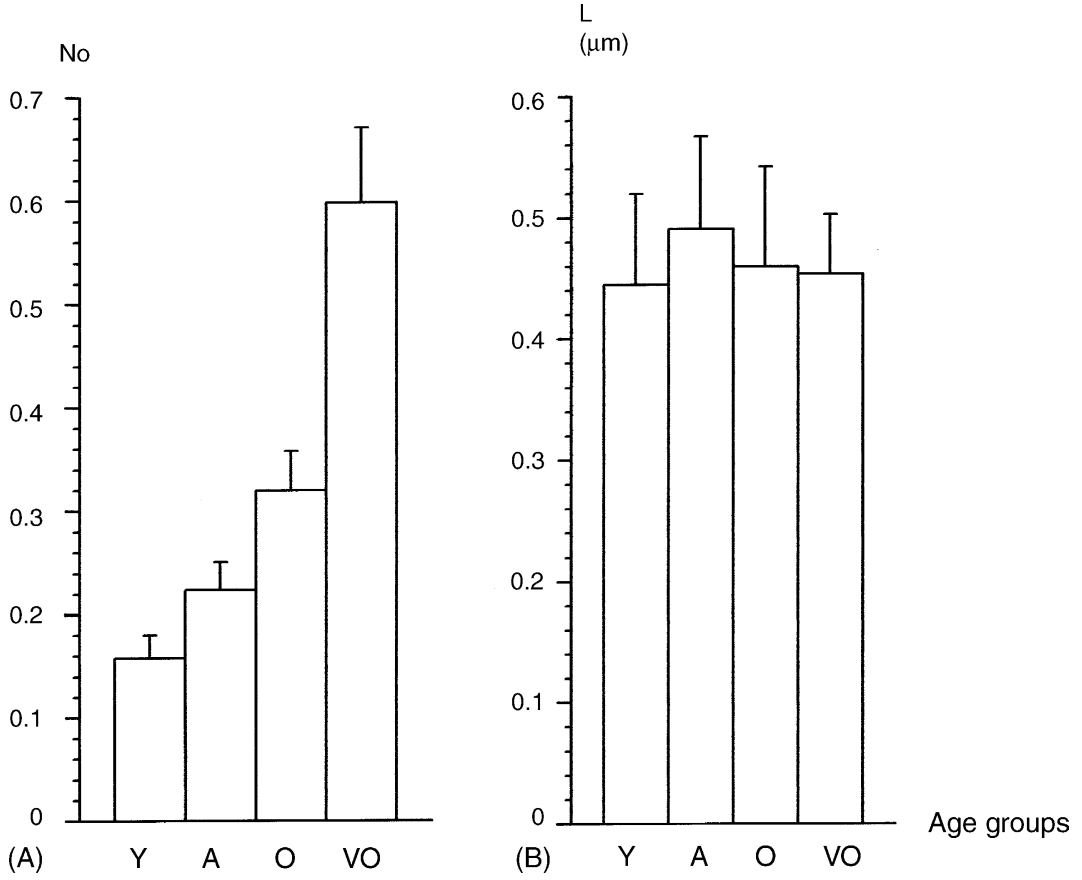

Fig. 2. (A) number (No) of gap junctions per unit of surface area $\left(100 \mu \mathrm{m}^{2}\right)$ of perineuronal satellite cells in rabbits aged 1 year (young, Y), 3.6 years (adult, A), 6.7 years (old, O), and 8.8 years (very old, VO). Values are means \pm S.E.M.: $\mathrm{Y}=0.158 \pm 0.022, \mathrm{~A}=0.224 \pm 0.027, \mathrm{O}=0.320 \pm 0.038$, and $\mathrm{VO}=0.598 \pm 0.073$. The differences between $\mathrm{Y}$ and $\mathrm{A}$, and between $\mathrm{A}$ and $\mathrm{O}$ are not significant $(P<0.01$, Tukey test), whereas the differences between $\mathrm{Y}$ and $\mathrm{O}$, between $\mathrm{Y}$ and $\mathrm{VO}$, between $\mathrm{A}$ and $\mathrm{VO}$, and between $\mathrm{O}$ and $\mathrm{VO}$ are significant $(P<0.01$, Tukey test). (B) length $(\mathrm{L})$ of individual gap junctions in perineuronal satellite cells of rabbits aged 1 year (young, Y), 3.6 years (adult, A), 6.7 years (old, O), and 8.8 years (very old, VO). Values are means \pm S.E.M.: $\mathrm{Y}=0.445 \pm 0.075$, $\mathrm{A}=0.487 \pm 0.076, \mathrm{O}=0.460 \pm 0.082$, and $\mathrm{VO}=0.454 \pm 0.049$. These values did not differ significantly (ANOVA).

if they are cocultured with astrocytes (e.g. see [21]). This and other data indicate that astrocytes play a neuroprotective role. In sensory ganglia, each neuron is usually enveloped by an individual satellite cell sheath whose outer contour faces the interstitial connective tissue containing capillaries. Thus, all substances from the blood must pass through the satellite cell sheath to reach the neuron. Since neurons in sensory ganglia lack the protection provided to central nervous system neurons by the blood-brain barrier, only the satellite cell sheath controls the traffic of substances to the ganglionic neuron. Therefore, the satellite cells in these ganglia are well placed to perform a neuroprotective function. Recent findings [37] support this hypothesis. That gap junctions participate in the neuroprotection carried out by astrocytes, is indicated by the finding that the blockade of gap junctional communication between these cells results in a markedly enhanced neuronal vulnerability to oxidative damage [3]. Gap junctions between perineuronal satellite cells are likely to have a similar role.

The permeability of gap junctions in non-nervous tissues $[9,34,36]$, in the central nervous system [31], and in spinal ganglia [15] is regulated by a number of conditions. In the absence of data on the gap junction permeability in satellite cells of various ages, it is not clear what influence the age changes in number and density of gap junctions have on the functions of perineuronal satellite cells. Nevertheless, our results indicate that the junctional system which provides morphological support for the metabolic cooperation between satellite cells in rabbit spinal ganglia becomes more extensive with advancing age.

Gap junctions consist of connexins, a family of closely related proteins, whose members are identified according to their predicted molecular mass in $\mathrm{kDa}$ (for review, see [1]). Several connexins have been detected in the nervous system. Among neuroglial cells, the vast majority of astrocytes express connexin 43 , oligodendrocytes express mainly connexin32, while Schwann cells express a variety of connexins but mainly 32 and 46 (for reviews, see [5,8,10,23,35,39]). However, little information is available on the connexins expressed by satellite cells in sensory ganglia. The only study we are aware of was carried out on the rat petrosal ganglion, where immunostaining for connexin 43 was present in satellite cells enveloping large neurons, but absent from those enveloping other neurons [6]. Future studies should aim to establish: (1) what connexins are expressed by perineuronal satellite cells in spinal ganglia, and (2) whether these connexins remain the same throughout life or change with age.

\section{References}

[1] M.V.L. Bennett, L.C. Barrio, T.A. Bargiello, D.C. Spray, E. Hertzberg, J.C. Sáez, Gap junctions: new tools, new answers, new questions, Neuron 6 (1991) 305-320.

[2] E.C. Beyer, Gap junctions, Int. Rev. Cytol., vol. 137C, Academic Press, San Diego/New York/Boston/London/Sydney/Tokyo/Toronto, 1993, pp. 1-37. 
[3] E.M. Blanc, A.J. Bruce-Keller, M.P. Mattson, Astrocytic gap junctional communication decreases neuronal vulnerability to oxidative stress-induced disruption of $\mathrm{Ca}^{2+}$ homeostasis and cell death, J. Neurochem. 70 (1998) 958-970.

[4] M.W. Brightman, T.S. Reese, Junctions between intimately apposed cell membranes in the vertebrate brain, J. Cell Biol. 40 (1969) 648-677.

[5] R. Bruzzone, T.W. White, D.L. Paul, Connections with connexins: the molecular basis of direct intercellular signaling, Eur. J. Biochem. 238 (1996) 1-27.

[6] J. Chen, L. He, B. Dinger, L. Stensaas, S. Fidone, Chronic hypoxia upregulates connexin43 expression in rat carotid body and petrosal ganglion, J. Appl. Physiol. 92 (2002) 1480-1486.

[7] M.L. Cotrina, Q. Gao, J.H.-C. Lin, M. Nedergaard, Expression and function of astrocytic gap junctions in aging, Brain Res. 901 (2001) 55-61.

[8] R. Dermietzel, D.C. Spray, Gap junctions in the brain: where, what type, how many and why? Trends Neurosci. 16 (1993) 186-192.

[9] M.O.K. Enkvist, K.D. McCarthy, Astroglial gap junction communication is increased by treatment with either glutamate or high $\mathrm{K}^{+}$ concentration, J. Neurochem. 62 (1994) 489-495.

[10] C. Giaume, K.D. McCarthy, Control of gap-junctional communication in astrocytic networks, Trends Neurosci. 19 (1996) 319-325.

[11] M. Hanani, T.Y. Huang, P.S. Cherkas, M. Ledda, E. Pannese, Glial cell plasticity in sensory ganglia induced by nerve damage, Neuroscience 114 (2002) 279-283.

[12] J.E. Harkness, J.E. Wagner, The Biology and Medicine of Rabbits and Rodents, second ed., Lea and Febiger, Philadelphia, 1983.

[13] L. Hertz, Regulation of potassium homeostasis by glial cells, in: G. Levi (Ed.), Differentiation and Functions of Glial Cells, Wiley-Liss, New York, 1990, pp. 225-234.

[14] K. Holthoff, O.W. Witte, Directed spatial potassium redistribution in rat neocortex, Glia 29 (2000) 288-292.

[15] T.-Y. Huang, P.S. Cherkas, D.W. Rosenthal, M. Hanani, Dye coupling among satellite glial cells in mammalian dorsal root ganglia, Brain Res. 1036 (2005) 42-49.

[16] R.O. Kelley, K.G. Vogel, H.A. Crissman, C.J. Lujan, B.E. Skipper, Development of the aging cell surface. Reduction of gap junctionmediated metabolic cooperation with progressive subcultivation of human embryo fibroblasts (IMR-90), Exp. Cell Res. 119 (1979) 127-143.

[17] H. Kettenmann, B.R. Ransom, Neuroglia, Oxford University Press, New York/Oxford, 1995.

[18] P. Kofuji, E.A. Newman, Potassium buffering in the central nervous system, Neuroscience 129 (2004) 1045-1056.

[19] A.R. Lieberman, Sensory ganglia, in: D.N. Landon (Ed.), The Peripheral Nerve, Chapman and Hall, London, 1976, pp. 188-278.

[20] T. Mattfeldt, G. Mall, H. Gharehbaghi, P. Möller, Estimation of surface area and length with the orientator, J. Microsc. 159 (1990) 301-317.

[21] M.P. Mattson, B. Rychlik, Glia protect hippocampal neurons against excitatory amino acid-induced degeneration: involvement of fibroblast growth factor, Int. J. Dev. Neurosci. 8 (1990) 399-415.

[22] P. Mobbs, H. Brew, D. Attwell, A quantitative analysis of glial cell coupling in the retina of the axolotl (Ambystoma mexicanum), Brain Res. 460 (1988) 235-245.
[23] J.I. Nagy, J.E. Rash, Connexins and gap junctions of astrocytes and oligodendrocytes in the CNS, Brain Res. Rev. 32 (2000) 2944.

[24] E.A. Newman, Glial cell regulation of extracellular potassium, in: H. Kettenmann, B.R. Ransom (Eds.), Neuroglia, Oxford University Press, New York/Oxford, 1995, pp. 717-731.

[25] E. Pannese, The histogenesis of the spinal ganglia, Advances in Anatomy, Embryology, and Cell Biology, vol. 47/5, Springer-Verlag, Berlin/Heidelberg/New York, 1974.

[26] E. Pannese, The satellite cells of the sensory ganglia, Advances in Anatomy, Embryology, and Cell Biology, vol. 65, Springer-Verlag, Berlin/Heidelberg/New York, 1981.

[27] E. Pannese, Neurocytology, Fine Structure of Neurons, Nerve Processes, and Neuroglial Cells, Georg Thieme Verlag, Stuttgart/New York, 1994.

[28] E. Pannese, L. Luciano, E. Reale, Intercellular junctions in developing spinal ganglia, Zoon 6 (1978) 129-138.

[29] E. Pannese, M. Ledda, P.S. Cherkas, T.Y. Huang, M. Hanani, Satellite cell reactions to axon injury of sensory ganglion neurons: increase in number of gap junctions and formation of bridges connecting previously separate perineuronal sheaths, Anat. Embryol. 206 (2003) 337-347.

[30] J.P. Revel, M.J. Karnovsky, Hexagonal array of subunits in intercellular junctions of the mouse heart and liver, J. Cell Biol. 33 (1967) C7-C12.

[31] N. Rouach, E. Avignone, W. Même, A. Koulakoff, L. Venance, F. Blomstrand, C. Giaume, Gap junctions and connexin expression in the normal and pathological central nervous system, Biol. Cell 94 (2002) 457-475.

[32] N. Rouach, A. Koulakoff, C. Giaume, Neurons set the tone of gap junctional communication in astrocytic networks, Neurochem. Int. 45 (2004) 265-272.

[33] G.G. Somjen, Electrophysiology of neuroglia, Annu. Rev. Physiol. 37 (1975) 163-190.

[34] D.C. Spray, A.L. Harris, M.V.L. Bennett, Gap junctional conductance is a simple and sensitive function of intracellular $\mathrm{pH}$, Science 211 (1981) 712-715.

[35] D.C. Spray, H.S. Duffy, E. Scemes, Gap junctions in glia. Types, roles, and plasticity, in: R. Matsas, M. Tsacopoulos (Eds.), The Functional Roles of Glial Cells in Health and Disease. Dialogue between Glia and Neurons, Kluwer Academic/Plenum Publisher, New York, 1999, pp. 339-359.

[36] C.-M. Tang, P.M. Orkand, R.K. Orkand, Coupling and uncoupling of amphibian neuroglia, Neurosci. Lett. 54 (1985) 237-242.

[37] T. Thippeswamy, J.S. McKay, R. Morris, J. Quinn, L.-F. Wong, D. Murphy, Glial-mediated neuroprotection: evidence for the protective role of the NO-cGMP pathway via neuron-glial communication in the peripheral nervous system, Glia 49 (2005) 197210 .

[38] S.H. Weisbroth, R.E. Flatt, A.L. Kraus, The Biology of the Laboratory Rabbit, Academic Press, New York/San Francisco/London, 1974.

[39] H. Wolburg, A. Rohlmann, Structure-function relationship in gap junctions Int. Rev. Cytol., vol. 157, Academic Press, San Diego/ New York/Boston/London/Sydney/Tokyo/Toronto, 1995, pp. 315373 